Research Article

\title{
Reinstatement and Lectotypification of Memecylon deccanense (Melastomataceae): An Endemic Species of the Western Ghats, India
}

\author{
E S Santhosh Kumar*, R Raj Vikraman, S Shailajakumari, P K Suresh Kumar, R S Sreelekshmy \\ Jawaharlal Nehru Tropical Botanic Garden and Research Institute (JNTBGRI), Kerala 695562, India
}

Article history:

Submission August 2019

Revised March 2020

Accepted April 2020

*Corresponding author:

E-mail:

santhoshkumares@gmail.com

\begin{abstract}
As part of the ex-situ conservation of the wild ornamental plants at JNTBGRI, several species of Memecylon were collected and introduced from the Western Ghats. While working on the taxonomy of the collected plants, it was found that a well-defined species Memecylon deccanense C.B.Clarke has been reduced recently to the synonym of M.heyneanum Benth. ex Wight \& Arn. A detailed study by relevant literature, live and herbarium specimens, and type specimens housed at different herbaria, it is reinstated as a distinct species and a lectotype is designated here. Relevant photographs and images of type specimens of M.deccanense and M.heyneanum also provided to facilitate its easy identification. Memecylon deccanense hence treated here as a distinct species from $M$. heyneanum.
\end{abstract}

Keywords: Memecylon deccanense, endemic, Western Ghats, Lectotypification

\section{Introduction}

Memecylon, a paleotropical genus belongs to the family Melastomataceae, consists of about 345 species worldwide (www.melastomataceae.net/MELnames/). In India, 53 species and 7 varieties have been recorded [1], of which 34 species and 2 varieties are occurring in the Western Ghats including 22 endemic taxa [2].

Memecylon deccanense was described by Charles Baron Clarke in 1879, based on Robert Wight's collection from the Deccan Peninsula. The precise locality of this rare plant was not known until Gamble (1919) [3] mentioned it for West Coast in Malabar and Travancore at lower levels. Since its original collection, it was also collected by M.A. Lawson and T.F. Bourdillon from the low-level evergreen forests of Travancore. Mohanan et al. (1980) [4] relocated this species from the Thiruvananthapuram district of Kerala after eight decades from its last gathering made by T.F.Bourdillon. Shailajakumari et al. (2016) [5] provided a detailed taxonomic account with photographs for this endangered species during her floristic inventorisation of the sacred groves of

\section{Kollam district in Kerala.}

M. heyneanum Benth. ex Wight \& Arn., is another endemic species of the Western Ghats, very closely similar to $M$. deccanense. It was originally proposed by George Bentham as a nomen nudum (Wallich Catalogue, http://wallich.rbge.info/search/node/memecylon) in 1831, which was later effectively validated by Wight and Arnott in 1834. While addressing certain nomenclatural problems pertaining to Indian species of Memecylon, Das et al. (2018) [1] designated a lectotype for M. heyneanum, but they erred in treating $M$. deccanense to the synonym of $M$. heyneanum, stated that both were described based on same type. It is evident that Wight and Arnott (1834) [6] had used two collections (Wallich's cat.n.4102 and Wight 1060) while validated M. heyneanum. Both collections were from the Deccan Peninsula, of which the later collection (Wight 1060) was ably used by C.B. Clarke for the description of $M$. deccanense. He explicitly excluded Wallich's cat. n.4102 from $M$. deccanense. Since it is very clear from the protologue that $M$. heyneanum and $M$. 
deccanense are not based on same type, but from different types mentioned above. Perusal of relevant literature, type specimens, living and other herbarium specimens we found that the two species can be easily distinguished from each other, hence $M$. deccanense is reinstated as distinct species from $M$. heyneanum and a lectotype is designated here. The confusion existed on the identity of these two closely related species are clarified here.

\section{Material and Methods}

The present work is based on examination of the relevant literature and field study of living plants as well as herbarium specimens housed at K, E, M, G, and GDC through high resolution images accessed at https://jstor.org. Several accessions of herbarium specimens were also have been studied at TBGT for the preparation of the description. Photographs were taken from its original habitat as well as from the living plants from our field gene bank for the wild ornamental plants.

\section{Result and Discussions}

Memecylon deccanense C.B. Clarke in Hook.f., Fl. Brit. India 2: 560.1879 (Figure 1 and 2). Type: INDIA, Deccan Peninsula, Wight 1060, (K000357774-Lectotype designated here, K).

Large profusely branched shrubs, up to $2 \mathrm{~m}$ high. Branchlets terete; bark grey- brown, shallowly fissured. Leaves opposite decussate in new shoots, later opposite superposed , 8-17 × 2.5-5 $\mathrm{cm}$, oblong-lanceolate, cordate or rounded at base, entire or very slightly revolute at margin, acuminate at apex, dark green above, pale beneath, coriaceous; mid rib prominent, intramarginal veins obscure, lateral nerves 18-22 pairs, obscure, drying pale green; petiole to $2.5 \mathrm{~mm}$ long, terete, glabrous. Inflorescence axillary or lateral, umbellate cymes, 15-22 mm across, 20-40 flowers per inflorescence; peduncle 3-5 mm long, sub-quandrangular; pedicels $2-3 \mathrm{~mm}$ long, slender, glabrous, pink. Bracts 0.5-0.8 mm long, ovate, hairy within. Flower buds obtuse at apex with exposed petals. Flowers 3-4 mm across, blue. Calyx 1.5-1.8 mm across, pink, saucer shaped above the ovary, shallowly 4-lobed, papillose without, disc rays faint. Petals 4, broadly elliptic-ovate, to $2 \times 2.5 \mathrm{~mm}$, shortly clawed at base, acute at apex. Stamens 8 , equal; filaments $2.5-3 \mathrm{~mm}$ long, pink-violet,

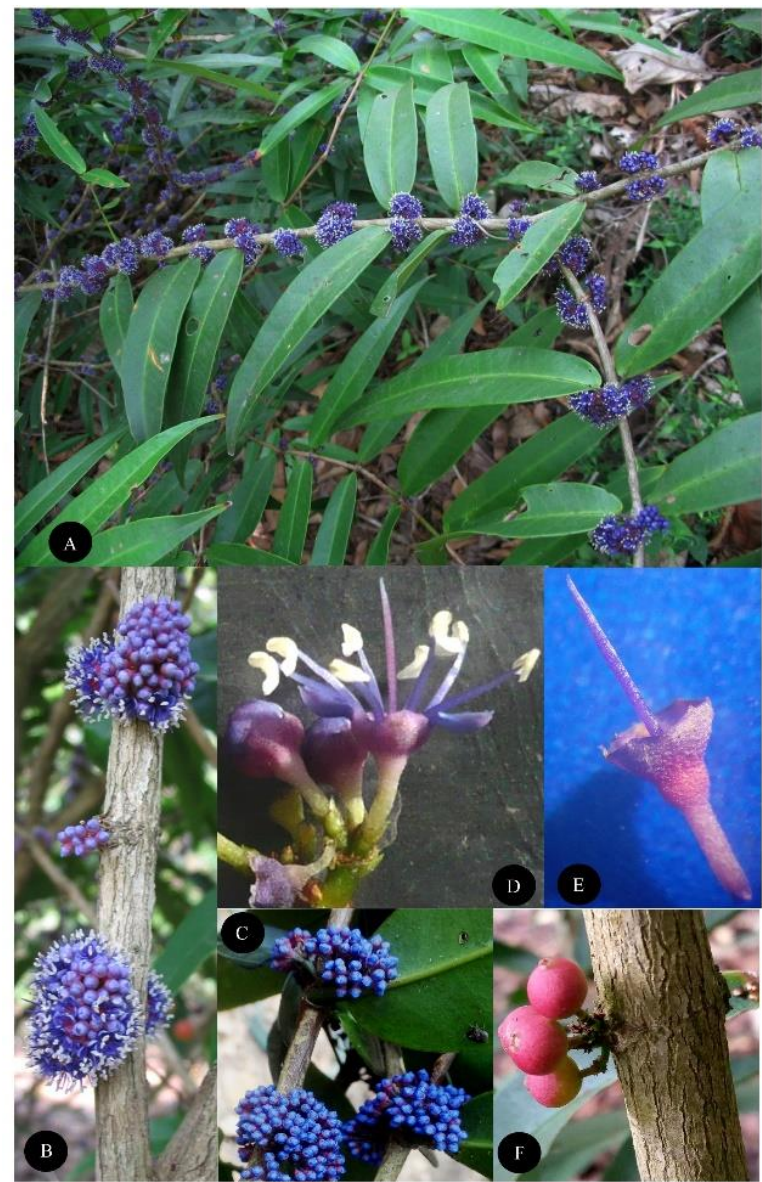

glabrous; anthers curved, connective with a gland, ca. $1 \mathrm{~mm}$ long, white. Ovary unilocular, placentation

Figure 1. Memecylon deccanense C.B. Clarke: A. Habit B. Stem with inflorescence C. Inflorescence shows flower and flower buds D. An opened flower E. Calyx with pistil F. Fruits.

free central, 6-ovuled; style subulate, to $4 \mathrm{~mm}$ long; stigma simple. Berries globose, $7-8 \mathrm{~mm}$ across, yellowish-green turning red-black at maturity.

\section{Flowering and fruiting: April-November}

\section{Habitat and associated species}

$M$. deccanense is rarely seen in semi-evergreen and in low level sacred groves of Kerala. The main associated species are Chassalia curviflora (Wall.) Thwaites, Cinnamomum malabatrum (Burm.f.) J.Presl, Ixora nigricans R.Br ex Wight \& Arn., Pothos scandens L., Xanthophyllum flavescens Roxb. 


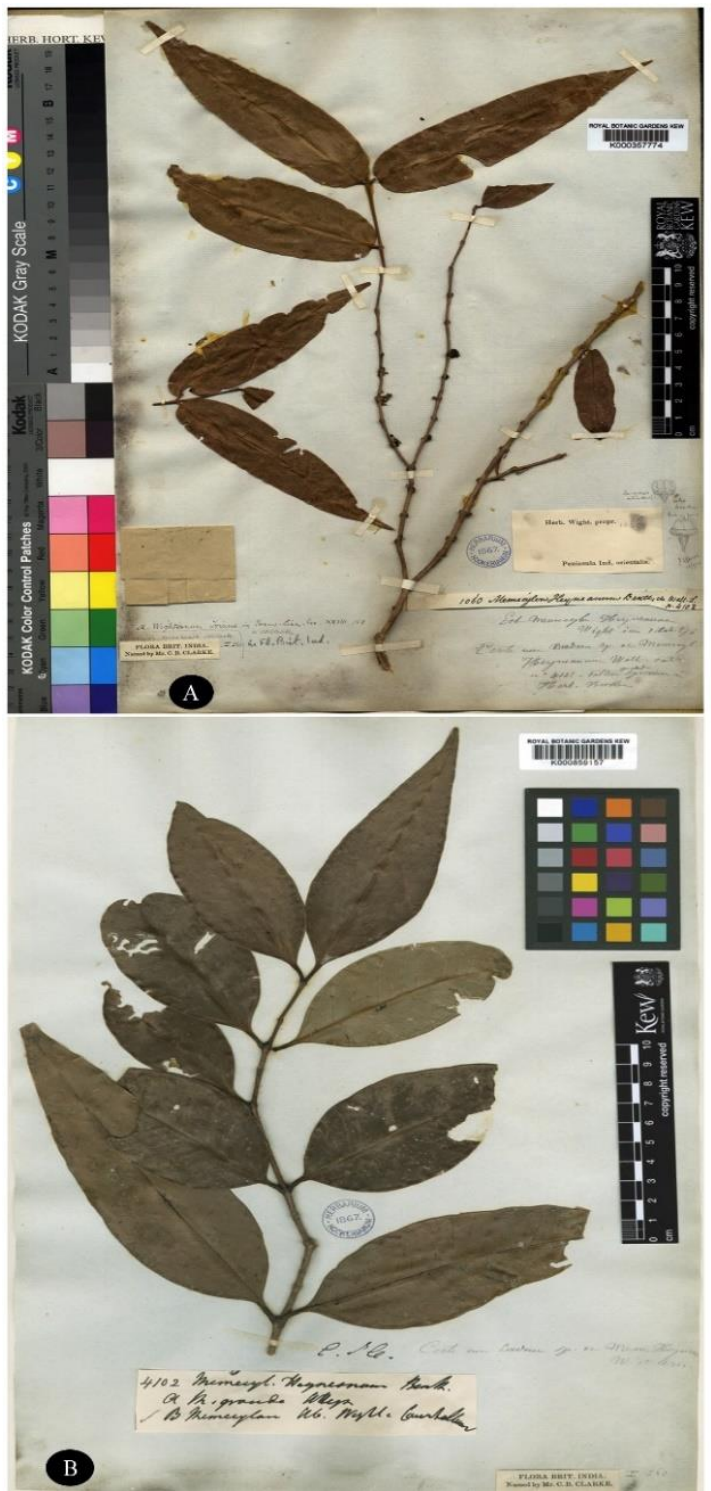

Figure 2. A. Lectotype of Memecylon deccanense C.B.Clarke (Wight 1060, K, barcode K000357774) B. Lectotype of M.heyneanum Benth. ex Wight \& Arn. (Wallich list n. 4102B, K, barcode K000859157).

\section{Distribution}

Endemic to the southern Western Ghats (Kerala and Tamil Nadu, India).

\section{Specimen examined}

Kerala state: Kollam district, Kulathupuzha, \pm 90 m, 26 November, 1893, M.A. Lawson 48 (CAL); Mandapathu Nagaraja Kavu, Pakalkuri, 15 January, 2015, S. Shailajakumari 068 (TBGT); Thiruvananthapuram district, Travancore, 20 January, 1894, T.F. Bourdillon 174728 (CAL); Venmaranelloor Kavu, E.S.Santhosh Kumar
47817 (TBGT);.Palode, E.S.Santhosh Kumar 70462 (TBGT)

\section{Lectotypification}

C.B. Clarke used Wight 1060 as the type of M.deccanense [7]. There are two sheets in K (there may be more sheets in $\mathrm{K}$ or elsewhere than can be seen on the internet!), one bearing Kew barcode number K000357774 with flowers, stem and leaves wand the other one (K000859159) with only stem and leaves. There are duplicates of this collection also available in E, but none of them seen by Clarke. Out of the two sheets at K, only one sheet (K000357774) is having a sticker denoted 'named by C.B.Clarke' in his own handwriting is most suitable for designated as the lectotype here (Figure 2).

\section{Conclusion}

$M$. deccanense is now reinstated to its original status as a distinct species from its allied species $M$. heyneanum. The later can be distinguished by the leaves with a well-developed petiole, acute at base, flowers sessile or very shortly pedicellate in fascicles on axillary and lateral tubercles, campanulate calyx etc., whereas in $M$. deccanense the leaves are sessile or shortly petiole, lamina rounded at base, flowers clearly pedicellate with axillary or lateral shortly pedunculate inflorescence, calyx above the ovary saucer shaped etc. It is seen endemic to the Kerala and Tamil Nadu regions of the Southern Western Ghats. Since it is an endangered species and a promising wild ornamental plant, it is worth to be introduced as a garden plant. Popularisation of the species through home gardens or public park will ensure its effective conservation.

\section{Acknowledgment}

The authors are grateful to the Director, JNTBGRI for the facilities and encouragements. They are thankful to the Board of Trustees, Royal Botanic Gardens, Kew for the permission granted for reusing the images of the type specimens. The third and fourth authors are thankful to M.S.University, Tirunelveli and University of Kerala respectively for the logistic supports.

\section{References}

1. Das MD, Pramanik A, Maity D (2018) Nomenclatural notes on some Indian species of Memecylon. Annales 
Botanici Fennici 55: $149 \quad-\quad 154$. doi: 10.5735/085.055.0118.

2. Nayar TS, Rasiya BA, Sibi M eds. (2014) Flowering Plants of the Western Ghats, India. Vol.1 Dicots. Jawaharlal Nehru Tropical Botanic Garden and Research Institute, Kerala.

3. Gamble JS (1919) Memecylon: Flora of the Presidency of Madras, Part III. Adlard \& Sons, London.

4. Mohanan M, Henry AN, Nair NC (1980) Some rare and fast disappearing plants discovered in Trivandrum district, Kerala, India. Bullettin of the Botanical Survey of India 22 (1-4): 105-108.
5. Shailajakumari S, Santhosh Kumar ES, Sreekala AK, Parthipan B (2016) Taxonomic note on Memecylon deccanense C.B.Clarke (Melastomataceae)-an endemic and endangered species of the Southern Western Ghats, India. International Journal of Advanced Life Sciences 9 (4): 524-526.

6. Wight R, Arnott GAW (1834) Prodromus Florae Peninsulae Indiae Orientalis. Vol.1. Parbury, Allen \& Co., London.

7. Clarke CB (1879) Melastomataceae In: Hooker, J.D. (Ed.) Flora of British India. Vol 2. L. Reeve \& Co., London. 